\author{
Ана Голубовић \\ Универзитет у Београду \\ Филолошки факултет
}

УДК 016:811.161.1+821.161.1.09=163.41

ДОИ https://doi.org/10.18485/

melissa.2016.15.1.ch10

\title{
САБРАНА И ИЗАБРАНА ДЕЛА РУСКЕ КЊИЖЕВНОСТИ У ПРЕВОДИМА НА СРПСКИ ЈЕЗИК
}

\author{
Анализа библиографске грађе
}

Библиографски подаци о преводима сабраних и изабраних дела руске књижевности на српски језик везани су за период од почетка XX века до савременог доба. Грађа коју чине сабрана и изабрана вишетомна дела руских књижевника преведена на српски језик, као и антологије дела руске књижевности црпи се, како из узајамног каталога Виртуелне библиотеке Србије, тако и из каталога и фондова Библиотеке Катедре за славистику Филолошког факултета БУ, каталога Библиотеке Српске академије наука и уметности, штампаних серија Библиографија Југославије и Српска библиографија: књиге 1868-1944.

Анализа доступне библиографске грађе пружа податке везане за развој преводилачке делатности и рецепцију руске књижевности у Србији, организацију обимних издавачких подухвата какву подразумева објављивање таквих целина, имена актуелних руских аутора у одређеним периодима, како за читалачку публику, тако и у области издаваштва, број и имена укључених преводилаца, уредника и издавача.

Кључне речи: руска књижевност у преводу на српски језик, сабрана дела, антологије, превођење, издаваштво.

Превођење дела руске књижевности на српски језик примило је значајније размере током друге половине XIX века. Новија руска књижевност је доживела процват у XIX веку а реформа српског језика средином столећа је допринела и зрелијем приступу преводилачкој делатности (SIBINOVIĆ 2015, 48).

Објављивање превода сабраних и изабраних дела појединих аутора, као и антологија дела стране књижевности обимни су организациони подухвати. У њима учествује велики број стручњака раз- 
нородних профила, где су уредници издавачних целина и преводиоци они са највишим ступњем одговорности. Подаци везани за развој преводилачке делатности и рецепцију руске књижевности у Србији, као и за организацију објављивања таквих целина могу се издвојити анализом библиографских података. На тај начин се може указати и на имена актуелних руских аутора у одређеним периодима, како за читалачку публику и у области издаваштва, али и у области научних истраживања и изучавања руске књижевности.

Период до Другог свестког рата обележило је публиковање сабраних дела класика руске књижевности Фјодора Михајловича Достојевског, Лава Николајевича Толстоја, Ивана Сергејевича Тургењева, Антона Павловича Чехова и Максима Горког у издањима Народне просвете и Народног дела. Већина тада објављених превода бележи многобројна прештампана издања у касније приређеним целинама. Издање Изабраних дела Ф. М. Достојевског из 1933. године представља један од обимнијих и професионалнијих подухвата тог типа у српској културној средини, под уређивачким вођством Исидоре Секулић. ${ }^{1}$ У уређењу дела Л. Н. Толстоја ${ }^{2}$ и И. С. Тургењева ${ }^{3}$ учестовали су Богдан Поповић и Милан Кашанин.

Прву деценију након Другог светског рата, у измењеним друштвено-политичким околностима и израженим утицајем соц-реализма, појавила су се у издању Културе, уз дела Максима Горког (1946-1952), ${ }^{4}$ и сабрана дела Михаила Александровича Шолохова 1963. године, ${ }^{5}$ уредника Милосава Бабовића, професора руске књижевности на Београдском универзитету (БАБовић 196?), као и хумориста Иљфа и

1 Изабрана дела : у 35 књига / Фјодор Михајлович Достојевски ; за штампу приредила Исидора Секулић. - Београд : Народна просвета, 1933 (Београд : Народна просвета). -35 т. ; $20 \mathrm{~cm}$

2 Изабрана дела / Лав Николајевич Толстој ; за штампу приредио Милан Кашанин. Београд : Народна просвета, 1933-1934 (Београд : Народна просвета). - 30 т. ; 21 cm

3 Сабрана дела / Иван Сергејевич Тургењев ; редакција Богдан Поповић, Исидора Секулић ; за штампу приредио Милан Кашанин. - Београд : Народна просвета, 19351936 (Београд : Народна просвета). - 20 т. ; $20 \mathrm{~cm}$

4 Дела / Максим Горки ; редактори Иво Андрић, Ивана Дубоковић, Вера Стојић, Божа Ковачевић, Милан Ђоковић, Вера Вујновић, Марко Видојковић. - Београд ; Загреб : Култура, 1946-1952 (Београд : Култура). - 27 т. : $20 \mathrm{~cm}$

5 Sabrana dela / Mihail Šolohov ; priredio Milosav Babović. - Beograd : Kultura, 1963 (Novi Sad : Budućnost). - 7 t. ; 17 cm. - (Biblioteka Kultura) 
Петрова, ${ }^{6}$ у издању Графичког завода из Титограда и Прогреса из Новог Сада наредне године.

Крај шездесетих година XX века обележила су четири значајна издања. Објављена су прва сабрана дела из области поезије 1966. године, Сергеја Александровича Јесењина у издању Народне књиге и Културе. ${ }^{7}$ Поново су приређена дела класика Фјодора Михајловича Достојевског у издању Рада (1967) 8 и Лава Николајевича Толстоја у сарадњи издавачких кућа Просвета и Рад (1968-1969). .9 Прва Сабрана дела Николаја Васиљевича Гогоља приредили професори Радован Лалић и Милосав Бабовић за Народну књигу из Београда и Обод из Цетиња 1970. године. ${ }^{10}$ Издваја се и тротомно издање Исака Бабеља из 1967. године. ${ }^{11}$ Приређивач, Миливоје Јовановић, одбранио је докторску дисертацију с темом из те области две године раније (JoVANOVIć 1965).

Током седемдесетих година XX века објављена су сабрана дела Александра Сергејевича Пушкина у издању Рада и редакцији Милорада Павића (1972. и 1979), ${ }^{12}$ Ивана Сергејевича Тургењева у издању Матице српске, приређивача Милорада Ђурића (1973), ${ }^{13}$ Михаила Јурјевича Љермонтова у издању Рада и редакцији Миодрага Сибиновића (1980), ${ }^{14}$ што се може тумачити и интензивнијим

6 Izabrana djela / Iljf i Petrov ; ur. Milorad Stojović. - Titograd : Grafički zavod ; Novi Sad : Progres, 1964 (Titograd : Grafički zavod). -5 t. ; $17 \mathrm{~cm}$. - (Biblioteka Minjoni)

7 Сабрана дела / Сергеј Јесењин; редакциони одбор Милорад Живанчевић, Миодраг Сибиновић, Никола Бертолино. - Београд : Народна књига : Култура, 1966 (Београд : Култура). -5 т. : илустр. ; $20 \mathrm{~cm}$

8 [Izabrana dela] / Fjodor Mihajlovič Dostojevski. - Beograd : Rad, 1967 (Beograd : Beogradski grafički zavod). - 13 t. ; $20 \mathrm{~cm}$. - (Odabrana dela svetskih klasika)

9 Сабрана дела / Лав Николајевич Толстој. - Београд : Просвета : Рад, 1968-1969 (Љубљана : Дело). - 20 т. ; $20 \mathrm{~cm}$

10 Сабрана дела / Николај Васиљевич Гогољ ; редакција Радован Лалић, Милосав Бабовић. - Београд : Народна књига ; Цетиње : Обод, 1970 (Цетиње : Обод). - 5 т. ; 20 cm

11 Сабрана дела / Исак Бабељ ; избор, редакција и превод Миливоје Јовановић. - Нови Сад : Матица српска, 1967 (Нови Сад : Будућност). - 3 т. ; $21 \mathrm{~cm}$

12 Sabrana dela / Aleksandar Sergejevič Puškin ; redakcija Milorad Pavić ; ilustrovano crtežima Aleksandra Puškina. - Beograd : Rad, 1972 (Ljubljana : Delo). - 8 t. ; $21 \mathrm{~cm}$

Sabrana dela / Aleksandar Sergejevič Puškin ; redakcija Milorad Pavić ; ilustrovano crtežima Aleksandra Puškina. - Beograd : Rad, 1979 (Ljubljana : Delo). - 8 t. ; $21 \mathrm{~cm}$

13 Изабрана дела / Иван Сергејевич Тургењев ; приредио Милорад Ђурић. - Нови Сад : Матица српска, 1973 (Нови Сад : Будућност). - 10 т. ; $20 \mathrm{~cm}$

14 Sabrana dela / Mihail Jurjevič Ljermontov ; izbor, predgovor i komentari Miodraga Sibinovića ; likovna oprema Jelena Grujičić-Majstorović. - Beograd : Rad, 1980 (Novi Sad : Budućnost). $-3 \mathrm{t}$. : ilustr ; $20 \mathrm{~cm}$. - (Odabrana dela svetskih klasika) 
интересовањем за период романтизма (СиБиновић 1971) (SToנNIć 1972). Објављена су сабрана дела песника модернизма Владимира Владимировича Мајаковског, издавачке куће Веселин Маслеша у редакцији Изета Сарајлића $1975 .{ }^{15}$ и Бориса Леонидовича Пастернака у издању кућа Слово љубве и Просвета 1979. године. ${ }^{16}$ Сабрана дела Антона Павловича Чехова приредио је Милосав Бабовић 1974. године за издавачку кућу Рад. ${ }^{17}$ Докторску дисертацију базирану на тумачењу Чеховљевих дела одбранио је 1977. године Зоран Божовић, преводилац и касније приређивач (Božovı́́ 1977). У периоду између 1970. и 1980. године издавачка кућа Рад публиковала је шест издања сабраних дела С. А. Јесењина под уредништвом Миодрага Сибиновића, Милорада Живанчевића и Николе Бертолина, што представља јединствен случај у српској културној средини.

Наредну декаду обележила су поновљена издања сабраних дела Ф. М. Достојевског $(1981,1983,1986,1988)$ и Л. Н. Толстоја $(1981,1983,1986)$. У сарадњи издавачких кућа Југославија и Просвета објављен је 1982. године превод Сабраних руских бајки које је сакупио Александар Николајевич Афанасјев. ${ }^{18}$ Објављена су и дела Михаила Афанасјевича Булгакова 1985. године, ${ }^{19}$ које су уредили Миливоје Јовановић и Милан Чолић у издању Српске књижевне задруге и Народне књиге (Jovanović 1975, 1989). Тротомна изабрана дела Марине Ивановне Цветајеве из 1990. године последње су приређена издања тог типа пред деценију у којој су уследиле значајне промене у научној и културној сфери. ${ }^{20}$ Издање које се извојило у том перио-

15 Izabrana djela / Vladimir Vladimirovič Majakovski ; urednik Izet Sarajlić. - Sarajevo : „Veselin Masleša", 1975 (Sarajevo : Oslobođenje). - 5 t. ; 20 cm. - (Biblioteka Svjetski klasici)

16 Dela / Boris Pasternak ; priredio za štampu Sveta Lukić. - Beograd : Slovo ljubve : Prosveta, 1979 (Novi Sad : Budućnost). -5 t. ; $21 \mathrm{~cm}$

17 Сабрана дела / Антон Павлович Чехов ; избор и предговор Милосав Бабовић. Београд : Рад, 1974 (Београд : Просвета). - 10 т. ; 20 cm. - (Одабрана дела светских класика)

18 Sabrane ruske bajke / Aleksandar Nikolajevič Afanasjev; urednik Stanislava Radovanović. - Beograd : Jugoslavija : Prosveta, 1982 (Ljubljana : Tiskarna Ljudske pravice). - 8 t. ; 19 cm. - (Biblioteka Svetovi mašte. Veliki klasici bajki)

19 Дела / Михаил Булгаков ; приредили Миливоје Јовановић, Милан Чолић. - Београд : Српска књижевна задруга : Народна књига, 1985 (Београд : Култура). - 8 т. ; $21 \mathrm{~cm}$

20 Izabrana dela / Marina Cvetajeva ; priredila Milica Nikolić. - Beograd : Narodna knjiga ; Beograd : Srpska književna zadruga, 1990 (Beograd : Slobodan Jović). - 3 t. ; 21 cm 
ду јесте оно фототипско сабраних дела Ф. М. Достојевског из 1933, које је објавила кућа Глас цркве 1994. године. ${ }^{21}$ Друштвено-политичка дешавања допринела су да се послови превођења и приређивања књижевних дела другачије организују. Велике издавачке куће које су их деценијама неговале место су уступиле новим, мањим, приватним колективима.

За период од почетка XXI века карактеристична су прештампана издања из претходних деценија невеликих издавачких кућа које на тај начин не сносе трошкове ауторских хонорара писаца, преводилаца и приређивача. Појава пиратерије и недовољне правне регулисаности су појаве које наводе теоретичари као главне проблеме (SIBINOVIĆ $2015,167-169)$. Посебно се у том смислу издвајају издања аутора чија дела чине школску лектиру. Са друге стране, слободно тржиште пружило је могућност да се, у потрази за новим читаоцима, понуда прошири и буде актуелна. Новину представљају издавачке целине дела Нине Николајевне Берберове у издању Паидеие (2001-2003), ${ }^{22}$ Данила Ивановича Хармса у издању Логоса и уредника Корнелије Ичин из 2005. године, ${ }^{23}$ као и Ивана Алексејевича Буњина које је приредио Никола Дробњаковић за Бернар 2010. године. ${ }^{24}$ Издавачке куће из Новод Сада су објавиле у протеклих неколико година изабрана дела појединих класика руске књижевности, у малом броју томова. То су: Антологија Пушкин (ур. Витомир Вулетић, изд. Прометеј, 2009); Изабрана дела Н. В. Гогоља (ур. Витомир Вулетић, Издавачка књижарница Зорана Стојановића, 2012); Изабрана дела А. П. Чехова (ур. Зоран Божовић, Издавачка књижарница Зорана Стојановића, 2013); Изабрана дела И. С. Тургењева (ур. Витомир Вулетић, Издавачка књижарница Зорана Стојановића, 2014).

21 Изабрана дела : у 35 књига / Фјодор Михајлович Достојевски ; за штампу приредила Исидора Секулић. - Фототипско издање из 1933. године. - Ваљево : Глас Цркве, 1994 (Београд : Београдски издавачко-графички завод). - 35 т. ; $20 \mathrm{~cm}$

22 Sabrana dela / Nina Berberova ; urednik Vesna Janjić. - Beograd : Paideia, 2001-2003 (Beograd : BIGZ). -7 t. ; $22 \mathrm{~cm}$

23 Сабрана дела / Данил Хармс ; уредник Корнелија Ичин. - Београд : Логос, 2005 (Београд : Зухра). - 2 т. ; $21 \mathrm{~cm}$

24 Изабрана дела / Иван Алексејевич Буњин ; приредио Никола Дробњаковић. - Стари Бановци ; Београд : Бернар, 2010 (Врњачка Бања : Интерклима-графика). - 6 т. : ауторова слика ; $21 \mathrm{~cm}$ 
Током XX века објављено је 56 целина, сабраних или изабраних дела аутора који припадају руској књижевности у преводу на српски (српскохрватски) језик. Од почетка XXI века укупно их је 16. Када су у питању антологије стваралаштва руских књижевника, сразмера је сасвим обрнута: XX век 10 а XXI век 18. Од оних приређених током XX века, две су објављене пре а осам након Другог светског рата. Број антологија поезије далеко премашује оне у којима су сабрана прозна дела. Међу њима се посебно издваја Антологија руске поезије у два тома коју је уредио Александар Петров 1977. године у издању Просвете по броју заступљених песника и ангажованих преводилаца. ${ }^{25}$

Антологијска издања XXI века такође карактерише већи број оних посвећених поезији. Међу њима су публикације које садрже дела ужег круга аутора и оне нису већег обима, попут издања која су приредили Миливоје Баћовић (Кад прште брезе, Без светлости нема ноћи), Драгиња Рамадански (Узводно од суза), Милан Вуковић (Дванаесторица) или Радојица Нешовић (Од Пушкина до Бродског). Такође, објављене су и антологије поезије специфичне тематике: Антологија поезије руског Београда уредника Остоје Ђурића; Сенка туге и светлост наде: антологија православне поезије руских песникиња Љубице Несторов; Мртве ће, у ирне усне, бела ноћ пољубити: антологија руске андерграунд поезије Светислава Травице; А где је твој дом?: антологија руске емигрантске поезије Зорана Ђерића. Издања која се издвајају као већи пројекти су тротомна Антологија руске лирике: XXXI век, коју је приредио Миодраг Сибиновић 2007. године за издвачку

25 АНТологИЈА руске поезије : XVII-XX век. Књ. 1 / избор, предговор и текстови о песницима Александар Петров ; првод Н. Бертолино, П. Вујичић, И. Грицкат, О. Давичо, Л. Захаров, Ј. Јовановић Змај, Д. Киш, Б. Ковачевић, З. Коцић, И. В. Лалић, И. Мамузић, Б. Миљковић, В. Николић, Р. Одавић, М. Павић, А. Петров, М. Пешић, С. Раичковић, М. Сибиновић, Љ. Симовић, К. Тарановски, М. Топић, Б. Ћосић, И. Хаџић, П. Чудић. - Београд : Просвета, 1977 (Нови Сад : Будућност). - 709 стр. ; 20 cm. (Светски класици ; коло 6 ; књ. 34)

АНТОЛОГИЈА руске поезије : XVII-XX век. Књ. 2 / избор, предговор и текстови о песницима Александар Петров ; првод О. Влатковић, П. Вујичић, О. Давичо, М. Данојлић, Л. Захаров, М. Јовановић, Д. Киш, Б. Миљковић, А. Петров, М. Пешић, С. Раичковић, М. Сибиновић, Љ. Симовић, Б. Ћосић, И. Хаџић, П. Чудић. - Београд : Просвета, 1977 (Нови Сад : Будућност). - 627 стр. ; 20 cm. - (Светски класици ; коло 6 ; 35) 
кући Паидеиа ${ }^{26}$ и Антологија руске поезије: XVII-XXI век у уредништву Александра Петрова и издању Завода за уџбенике из 2011,27 која је проширено издање антологије из 1977. године.

Међу антологијама прозног стваралаштва руских аутора прва се издваја Антологија руске фантастике XIX и XX века из 1966. године у уредништву Милице Николић. ${ }^{28}$ Селекцију прича XX века под насловом Сада кад сам се пробудио приредили су Миливоје Јовановић и Владимир Меденица 1995. године. ${ }^{29}$ На основу тог издања сачињена је и двотомна Антологија руске приче XX века 2004. истих уредника. ${ }^{30}$ У одабиру М. Јовановића објављена је и Проза Серапионове браће 2012. године. ${ }^{31}$ Издавачка кућа Бернар је подржала издање

26 АНТОЛОГИЈА руске лирике : X-XXI век / избор и белешке о писцима Миодраг Сибиновић. - Београд : Паидеиа, 2007 (Београд : БИГЗ). - 3 т. ; 21 cm. - (Библиотека Поезија)

27 АНТОЛОГИЈА руске поезије : XVII-XXI век / избор, предговор и текстови о песницима Александар Петров ; превод М. Баћовић, Н. Бертолино, О. Влатковић, П. Вујичић, И. Грицкат, О. Давичо, М. Данојлић, М. Живанчевић, Л. Захаров, Ј. Јовановић Змај, М. Јовановић, Р. Кавеџић, Д. Киш, Б. Ковачевић, З. Коцић, И. В. Лалић, Д. Максимовић, И. Мамузић, Р. Мечанин, Б. Миљковић, В. Николић, Д. Николић, Р. Одавић, М. Павић, А. Петров, М. Пешић, С. Раичковић, М. Сибиновић, Љ. Симовић, К. Тарановски, М. Топић, С. Травица, Б. Ћосић, И. Хаџић, В. Хорват, П. Чудић. - Београд : Завод за уџбенике, 2011 (Београд : Службени гласник). - 1034 стр. : слике аутора ; $25 \mathrm{~cm}$

28 ANTOLOGIJA ruske fantastike XIX i XX veka / priredila Milica Nikolić ; preveli Miroslav Babović, Nana Bogdanović, Lidija Dmitrijeva, Jelica Drenovac, Aleksandar Flaker, D. N. Jovanović, Milivoje Jovanović, Olga Kojić, Božidar Kovačević, Mira Lalić, Ljudmila Mihailović, Miloš Moskovljević, Milica Nikolić, M. M. Pešić, V. Poljakov, Lidija Subotin, Zorka Velimirović, Stanislav Vinaver, Lola Vlatković, Petar Vujičić. - Beograd : Nolit, 1966 (Beograd : Beogradski grafički zavod). - 595 str. ; 19 cm. - (Biblioteka Orfej ; knj. 36)

29 САДА кад сам се пробудио : антологија руске приче XX века : од Сологуба до Хармса / приредили Миливоје Јовановић, Владимир Меденица ; превод Корнелија Ичин, Мира Чехова, Миливоје Јовановић, Петар Вујичић, Мира Лалић, Милица Николић, Радослав Божић, Густав Крклец, Ирена Лукшић, Лидија Суботин, Миодраг М. Пешић, Дејан Михаиловић. - Београд : Логос : Ортодос : Ант, 1995 (Београд : Чигоја штампа). - 480 стр. ; $21 \mathrm{~cm}$. - (Библиотека Психократија)

30 АНТОЛОГИЈА руске приче XX века : у два тома : од Фјодора Сологуба до Јекатерине Садур / приредили Миливоје Јовановић и Владимир Меденица. - Београд : Плато, 2004 (Београд : Плато). - 2 т. ; 21 cm. - (Библиотека Психократия)

31 ПРОзА Серапионове браће / Лав Лунц, Вселовод Иванов, Венјамин Каверин, Николај Никитин, Николај Тихонов, Михаил Слонимски, Константин Феђин, Михаил Зошченко ; приредио и предговор написао Миливоје Јовановић ; превели с руског Миливоје Јовановић, Неда Николић-Бобић, Милош Добрић. - Београд : Логос, 2012 (Ужице : Графичар). - 717 стр. ; 22 cm. - (Библиотека Космополис) 
Антологија руске модерне приче уредника Владимира Јагличића у 4 тома 2011. ${ }^{32}$ и Антологија руске духовне прозе 2014. године. ${ }^{33}$

„Иницијатори и носиоци преводилачког уграђивања дела руских писаца у српску културу (...) од најстаријих времена до данас, увек су били истовремено и угледни српски књижевници, мислиоци, научници и интелектуалци" (SIBINOVIć 2015, 208). Научници и изучаваоци историје руске књижевности често су учествовали, како у пословима превођења, тако и при уређењу сабраних, изабраних дела и антологија: Милосав Бабовић, Радован Лалић, Зоран Божовић, Милош Московљевић, Петар Митропан, Миодраг Сибиновић, Мирослав Топић, Миливоје Јовановић и Корнелија Ичин. Међу бројним преводиоцима истакли су се: Никола Бертолино, Милорад Живанчевић, породица Максимовић - Јован, Десанка и Љубомир, Миодраг Пешић. Учешће жена и тим пословима било је карактеристично и у периоду пре Другог светског рата: Бранислава Бојовић Ковачевић, Зорка Велимировић, Станка Глишић, Људмила Михаиловић, Косара Цветковић.

Књижевници који су оставили траг и као преводиоци дела руске књижевности су: Јован Јовановић Змај, Јован Дучић, Милован Глишић, Милован Ђилас, Бранко Миљковић, Милорад Павић, Данило Киш, Љубомир Симовић, Бора ћосић, Милован Данојлић, Стеван Раичковић. Посебно место међу њима заузима Десанка Максимовић

(SIBINOVIć 2015, 192). Приликом рада на састављању сабраних дела песникиње откривен је и низ њених превода објављених под туђим именима, као и превода који су објављени под њеним именом а који су припадали Радовану Зоговићу (СиБиновић 2015, 98). Књижевници који су се ангажовали када су у питању били уређивачки послови су Исидора Секулић, за сабрана дела Ф. М. Достојевског, и Милорад Павић, за дела А. С. Пушкина.

32 АНтологИЈА руске модерне приче / избор Владимир Јагличић. - Стари Бановци ; Београд : Бернар, 2011. - 4 т. : слике аутора ; 22 cm. - (Библиотека Изабрана дела)

33 АНтологИјА руске духовне прозе : Руси у богу / избор Здравко Шћепановић. Крушчић : Панонске нити ; Стари Бановци ; Београд : Бернар, 2014 (Нови Сад : Сајнос). - 1197 стр. ; 25 cm. - (Библиотека Љубав и њен трећи двојник) (Библиотека Изабрана дела) 


\section{Литеартура}

БАБовић, Милосав. Песници и револуција: Александар Блок, Сергеј Јесењин, Владимир Мајаковски, Александар Фадејев, Исак Бабељ, Александар Серафимович, Леонид Леонов, Михаил Шолохов, Борис Пастернак. Београд: Слобода, 196?

ВинАвер, Надежда. „Јединство стваралачког процеса.” Prevodilac 30, 3/4 (2011), 48-63. ЈовАновић, Зоран Р. „Превођење као стваралачки чин.” Prevodilac 35, 1/2 (2016), 7-20.

ПИПЕР, Предраг. О преводима из руске књижевности: преводилачка читанка: избор, типологија и библиографија критичких текстова. Нови Сад: Филозофски факултет, 1985.

СиБиновић, Миодраг. „Изазови за даље проучавање живота и дела Десанке максимовић на грађи њених превода, есеја и путописа." Славистичке теме. Београд: Филолошки факултет, 2015: стр. 95-102.

СиБиновић, Миодраг. „Превод и култура данас.” Prevodilac 31, 3/4 (2012), 15-24.

СиБиновић, Миодраг. Љермонтов у српској књижевности :до другог светског pama. Београд: Филолошки факултет, 1971. (Монографије; 39)

BABović, Milosav. Dostojevski kod Srba. Titograd: Grafički zavod, 1961. (Biblioteka Studije ; 3) Božović, Zoran. Čehov kao dramski pisac kod Srba: doktorska disertacija. Beograd, 1977. Jovanović, Milivoje. Mihail Bulgakov: druga knjiga. Beograd: Novo delo, 1989. (Biblioteka Monografije, studije, kritika)

Jovanović, Milivoje. Umetnost Isaka Babelja: doktorska disertacija. Beograd, 1965.

Jovanović, Milivoje. Umetnost Isaka Babelja. Beograd: Filološki fakultet, 1975.

Jovanović, Milivoje. Utopija Mihaila Bulgakova. Beograd: Institut za književnost i umetnost, 1975. (Studije i rasprave; 13)

SıBınović, Milorad. Množenje svetova: ruski pisci u srpskoj prevodnoj književnosti. Beograd: Clio, 2015.

StoJnIĆ, Mila. Ruski pisci XIX i XX veka. Knj. 1. Sarajevo: Zavod za izdavanje udžbenika, 1972. (Nastavna biblioteka ; 59) 


\title{
Ana Golubović
}

\section{COLLECTED AND SELECTED WORKS OF RUSSIAN LITERATURE IN TRANSLATION INTO SERBIAN}

\author{
Analysis of Bibliographic Material
}

\begin{abstract}
Summary
Bibliographic data of the translations of collected and selected works of Russian literature into Serbian language are related to the period from the beginning of XX century to contemporary time. Materials consisting of collected and selected voluminous works of Russian writers translated into Serbian, as well as anthologies of works of Russian literature are drawn from both the union catalog of The Virtual Library of Serbia, as well as catalogs and funds of The Library of the Department of Slavistics, Philology Faculty of University of Belgrade, catalogues of The Library of the Serbian Academy of Arts and Sciences, printed serials The Bibliography of Yugoslavia and The Serbian Bibliography: Books 1868-1944.

Analysis of the available bibliographic material provides data related to the development of translation activity and reception of Russian literature in Serbia, organizing large-scale publishing ventures implied by the publication of such a continent, emphasizing current Russian authors in certain periods, both for readership, as well as in publishing, the number and names of involved translators, editors and publishers.
\end{abstract}

Key words: Russian literature translated into Serbian language, collected works, anthologies, translating, publishing. 